\title{
La sociedad como voluntad y representación: La teoría de la sociedad en la eudemonología schopenhaueriana
}

\author{
The society as will and representation: The theory of society in schopenhauerian \\ eudemonology
}

\author{
Juan David Mateu Alonso \\ Professor Associado do Dept. de Metafísica y Teoría del conocimiento \\ da Universidad de Valencia (Valência-Espanha) \\ E-mail:david.mateu@uv.es
}

\begin{abstract}
Resumen: En este artículo me ocupo de la teoría de la sociedad que Schopenhauer presenta en sus Aphorismen zur Lebensweisheit. En primer lugar, intento desarrollar la articulación de estos aforismos con el resto de su filosofía, de modo que analizo la génesis de la eudemonología especialmente en los manuscritos póstumos de 1826-1830. A continuación, utilizo la distinción entre voluntad y representación como herramienta hermenéutica para la interpretación de la teoría social de Schopenhauer: en el caso de la sociedad como representación, destaco la crítica schopenhaueriana del honor y sus implicaciones para la teoría de la sociedad y en el caso de la sociedad como voluntad, me centro en los factores de coacción y cohesión social. En la conclusión, apunto la relevancia de la teoría de la sociedad presente en la eudemonología para la filosofía política schopenhaueriana.
\end{abstract}

Palabras clave: Eudemonología; Filosofía social; Filosofía política.

Abstract: In this paper I am concerned with the theory of society that Schopenhauer presents in his Aphorismen zur Lebensweisheit. First, I try to develop the link of these aphorisms with the rest of his philosophy, so I analyze the genesis of eudemonology especially in the posthumous manuscripts of 1826-1830. My next step consists in using the distinction between will and representation as a hermeneutical tool for the interpretation of Schopenhauer's social theory: in the paragraph about society as representation, I focus on his criticism of honor and its implications for the theory of society and in the paragraph about society as will, I analyse the factors of social coercion and cohesion considered by Schopenhauer. In the conclusion, I highlight the importance of this social theory embedded in Schopenhauer's eudemonology for his political philosophy.

Keywords: Eudemonology; Social philosophy; Political philosophy.

\section{Introducción: el lugar de la eudemonología en la obra schopenhaueriana}

Desde un punto de vista histórico-biográfico, los Aforismos sobre la sabiduría de la vida se publicaron en 1851, dentro del primer volumen de los Parerga y Paralipómena (P/P), pero recogían reflexiones que venían cuajándose hacía décadas. El propio Schopenhauer reconoce su carácter "popular" y fue el escrito que, junto a los otros textos de P/P, le proporcionó el acceso a la fama. Como señala Rüdiger Safranski, sería erróneo pensar que este escrito logró la benvolencia del público debido al contexto socio-cultural de esa época de fracaso revolucionario, decepción, derrotismo y pesimismo; 
no sólo fermentó su pensamiento entre los desencantados, sino que también encontró su caldo de cultivo entre la burguesía progresista que no se veía representada por el materialismo, el positivismo o el evolucionismo que se estaban gestando en ese momento. En estos aforismos la ética de la compasión y la renuncia son suspendidas en favor de una ética del como si, en términos de Safranski, en la que se reintroduce el tema de la felicidad, de la eudemonología clásica, temática que atrajo a los tipos de público ya mencionados ${ }^{1}$.

La cuestión de la coherencia de Schopenhauer en lo que se refiere a la articulación de los Aforismos sobre la sabiduría de la vida con el resto de su ética y su ontología constituye un problema por sí mismo: la eudemonología allí ensayada sería el ejemplo negativo que habría denunciado hacia el final del segundo volumen de El mundo como voluntad y representación ${ }^{2}$. Es el propio Schopenhauer quien se encarga de apuntar esta dificultad en la introducción a sus aforismos:

Ésta [la eudemonología], precisamente, descansa sobre el error innato cuya reprensión inaugura el capítulo 49 del segundo volumen de mi obra principal. En consecuencia, para poder elaborar una tal eudemonología, he tenido que prescindir completamente de la más alta perspectiva metafísica y ética a la que conduce mi verdadera filosofía. Por consiguiente, toda la discusión que aquí se va a ofrecer en cierta medida descansa sobre una acomodación [Ackommodation], en tanto que permanece bajo la perspectiva empírica habitual y se aferra a su error. Por ello, su valor sólo puede ser condicional, puesto que incluso la palabra eudemonología es tan sólo un eufemismo ${ }^{3}$.

De este modo, ya en la introducción de los Aforismos Schopenhauer explicita la diferencia entre su "verdadera" filosofía, que niega que la vida humana pueda lograr la felicidad, y la eudemonología que va a ensayar y que supone una respuesta afirmativa a la posibilidad de una vida humana digna de ser calificada de feliz. Ahora bien, esa diferencia se concibe como una acomodación, esto es, como una adaptación o concesión a un punto de vista empírico, cotidiano, según Schopenhauer, prescindiendo por completo de la perspectiva metafísica y trascendental que habría guiado la mayor parte de sus reflexiones.

\footnotetext{
${ }^{1}$ «El pesimismo fundamental es amortiguado y la sabiduría para la supervivencia y la autoafirmación, criticada con frecuencia, experimenta una revalorización pragmática: si suponemos que la vida valiera la pena, ¿cómo deberíamos llevarla a cabo para lograr el óptimo de felicidad alcanzable? Ésta es la "filosofía para el mundo". Esta pone entre paréntesis el escándalo metafísico» (Safranski, 2001: 495). Por su parte, Robert Zimmer considera que no cumple esta función, sino que la eudemonología constituye «un complemento de la ética schopenhaueriana mediante una filosofía del arte de vivir» (Zimmer, 2010: 223). Considero que estas dos lecturas no plantean una disyunción excluyente; a mi juicio, los Aforismos sirven a la vez como una alternativa frente a la fuerte exigencia de la ética de la compasión y como un complemento que permite dar cohesión a su filosofía práctica, en especial, a la conexión entre ética, derecho y filosofía política, como se pretende mostrar aquí.

${ }^{2}$ Robert Zimmer ha utilizado una metáfora espacial para resaltar la diferencia entre El mundo y Parerga y Paralipómena: mientras que la primera adopta una interpretación "vertical" sobre el mundo y la naturaleza humana buscando en su interior, en la segunda el punto de vista es "horizontal", observando el trato humano en sociedad (Zimmer, 2009: 46).

${ }^{3}$ SCHOPENHAUER, A. P/P, I, p. 313.
} 
Ya en la interpretación que se haga de este texto del prólogo de los Aforismos está en juego el marco general en el que se va a insertar su análisis, y por ello conviene aclarar esta cuestión, para lo cual me serviré, entre otras, de las consideraciones de Volker Spierling y Rüdiger Safranski.

En primer lugar, podemos relativizar la propia afirmación de Schopenhauer, siguiendo a Safranski, según la cual la eudemonología pone entre paréntesis el sistema metafísico en general, ya que habría que tener en cuenta que el ideal de autarquía que esboza Schopenhauer presupone el mismo enemigo que se quería combatir mediante las otras formas de navegación, en definitiva, la voluntad. Así, incluso en los Aforismos sobre la sabiduría de la vida intervendría la negación de la voluntad, con lo que éstos no serían independientes del marco general de la metafísica de la voluntad ${ }^{4}$.

Y en el mismo sentido podríamos argumentar también con Volker Spierling que tanto la ética de la compasión como la eudemonología parten de la convicción de que lo positivo y real es el dolor y el sufrimiento, mientras que el placer y la felicidad son meramente negaciones parciales de lo anterior ${ }^{5}$. Pero no sólo coincidirían respecto al punto de partida, sino también respecto a la finalidad de ambas, pues el propio Spierling ha apuntado que la serenidad o alegría que Schopenhauer considera la raíz de la única felicidad posible presupone la identificación de la vida con el sufrimiento y por ello es tan apreciada: «Si en su metafísica Schopenhauer se ocupa en última instancia de la redención del sufrimiento [...], en los Aforismos se trata de una autosuficiencia en el sufrimiento» ${ }^{6}$.

Pero además de esta argumentación sistemática, desde un punto de vista histórico-genético, los Aforismos, pese a ser publicados en 1851, se habrían estado gestando a la vez que El mundo, pues ya en 1814 comienza a trabajar tanto sobre materiales que luego cristalizarían en su principal obra como en textos orientados hacia una sabiduría mundana, con lo que habría que relativizar la supuesta independencia de los Aforismos y el hecho de considerarla como alternativa a las otras dos. Como muestra de que ya en 1814 Schopenhauer estaba ocupado en estas cuestiones sobre la vida mundana como diferentes a las de la ética en sentido estricto valga este texto de los póstumos:

El principio de Aristóteles de atenerse al término medio en todas las cosas encaja mal como principio moral para lo cual lo concibió: pero fácilmente podría ser la mejor regla general de prudencia, el mejor precepto para la vida feliz. [...] El meden agan

\footnotetext{
${ }^{4}$ «La amortiguación de la voluntad pertenece de antemano a esta autarquía. Ha de predominar una capacidad de meditación que no proviene sólo de la sabiduría de la vida obligada por el principio de realidad, sino que contiene ya una cierta añadidura de negación de la voluntad. En esta medida Schopenhauer presupone en cierto sentido aquella "perspectiva metafísico-ética" que pretende ciertamente poner entre paréntesis» (Safranski, 2001: 496). En la misma línea de conexión fuerte entre eudemonología y metafísica apuntaría Robert Zimmer (Zimmer, 2009: 46).

5 «La convicción de Schopenhauer, según la cual todo placer y toda felicidad son negativos y que, por el contrario, el dolor es positivo, es de la mayor importancia tanto para los Aforismos como para su obra completa» (Spierling, 1994: 213).

${ }^{6}$ Spierling, 1994: 204-205. Spierling llega a hablar de un "Nirvana del día a día" (Spierling, 1994: 218-219), a diferencia de la nada con la que concluye el primer volumen de El mundo.
} 
[nada en exceso] y el nil admirari [no admirar nada] son reglas excelentes para la sabiduría de la vida [Lebensweisheit $]^{7}$.

En este texto se aprecia claramente que aquello que criticaba a Aristóteles respecto a la moral (recuérdese también por ejemplo la teoría del carácter) se convierte en elogio respecto a la sabiduría de la vida, diferencia que por tanto estaba ya inscrita desde un comienzo en el planteamiento de Schopenhauer.

Precisamente quisiera insistir en este punto: la sabiduría de la vida expuesta en los Aforismos no es una vía diferente e independiente de las otras expuestas por Schopenhauer, es decir, el ascetismo místico que negaba la voluntad o la redención por el sufrimiento; no es una navegación alternativa porque presupone estas formas anteriores y no pretende la negación de la voluntad, sino meramente evitar el sufrimiento en el ámbito mundano y social. Si esto es así, la eudemonología no consiste en otro modo de lograr la negación de la voluntad y la consiguiente redención, sino en dar cuenta de unos aspectos que precisamente aquella filosofía moral de la compasión dejaba de lado ${ }^{8}$.

La sabiduría mundana presupone las otras dos formas de redención (ascetismo y sufrimiento) y, según nuestra interpretación, es exigida tanto [1] para explicar y desarrollar el carácter adquirido, un concepto que había sido excluido de la ética de la compasión'; cuanto [2] para dar cuenta del ámbito social intersubjetivo que no era tematizado en su filosofía moral, esto es, para explicitar una teoría de la sociedad sobre la que erigir una determinada teoría del derecho y de la política. En este sentido, la eudemonología se puede entender como la plataforma que permite entender la conexión entre el pesimismo antropológico y la filosofía política schopenhaueriana. Este artículo intentará, por tanto, dilucidar la concepción de la sociedad que se configura en esta vertiente de la filosofía de Schopenhauer.

De este modo, los Aforismos no supondrían otra vía alternativa por sí misma para la consecución del objetivo práctico de la filosofía de Schopenhauer, sino que vendrían a complementar y tratar de suturar las brechas abiertas por su propia filosofía moral y concretamente aquí me centraré en la cuestión social ${ }^{10}$.

\footnotetext{
${ }^{7}$ SCHOPENHAUER, A. HN/MP, I, § 132, p. 81-82.

${ }^{8} \mathrm{Si}$ bien es innegable que la eudemonología necesita del trasfondo de la metafísica y la ética, no puedo estar de acuerdo con la posición de Barbara Neymeyr, quien además de reivindicar que la ética es el telón de fondo sobre el que entender la eudemonología, defiende que ésta es una fase previa (Vorstufe) para llegar a aquélla (Neymeyr, 1996: 165).

${ }^{9}$ Por ejemplo, dice Schopenhauer que el carácter adquirido «no es ciertamente tan importante para la ética auténtica como para la vida mundana [Weltleben], sin embargo, su aclaración se coordinaba con la del carácter empírico y el inteligible como el tercer tipo») (WWV/MVR, I, $\S 55$, p. 401). Hannan ha interpretado el carácter adquirido en términos de auto-realización, aunque no logra articular adecuadamente la alternativa que esto supone frente la ética (Hannan, 2009: 135).

${ }^{10}$ Recientemente Michel Onfray ha contrapuesto la "ontología negra" (pesimista) de Schopenhauer a su "ética blanca", argumentando a favor de una tesis de conexión sistemática entre ambas vertientes de su filosofía (Onfray, 2009: 210). Pese a aceptar en general esta tesis, no coincido con la definición de la ética blanca según Onfray, pues incluye aspectos muy
} 
Pese a que Schopenhauer diga en la introducción a estos Aforismos que en ellos va a poner su ontología entre paréntesis, como hemos señalado con Safranski, ésta supone un telón de fondo ineludible que permite explicar las críticas a la sociedad burguesa de su tiempo, ya que mientras, por una parte, dan lugar a la búsqueda de una autarquía y una persecución individual de la felicidad (burguesa, en cierto modo), ${ }^{11}$ por otra, alimentan una determinada visión del funcionamiento de la sociedad, es decir, de una teoría social y política ${ }^{12}$. Por ello, estos Aforismos juegan ese papel de bisagra entre la moral de la compasión y la teoría social y política, pues complementando las insuficiencias de la primera, ponen las bases de una teoría de la sociedad sobre las que erigir un planteamiento socio-político como el propuesto por Schopenhauer, que se va a caracterizar en primera instancia por defender una concepción liberal del Estado como institución cuya única misión ha de ser garantizar la seguridad, la integridad física y la propiedad de los particulares, concepción muy semejante a la de W. von Humboldt ${ }^{13}$.

\section{Los antecedentes de la eudemonología en la obra schopenhaueriana}

Ciertamente, como han apuntado Spierling y Hübscher ${ }^{14}$, la temática propia que se desarrolla en los Aforismos, publicados en 1851, tiene su punto de referencia en los textos póstumos de 1826-1830 (que luego se han publicado en castellano como El arte de ser feliz), época en que Schopenhauer trata

\footnotetext{
ligados a su metafísica pesimista; recordemos que para Schopenhauer la ética era la culminación de su metafísica, de modo que, siguiendo la metáfora cromática, sería más adecuado hablar de una eudemonología gris, frente a su metafísica y ética (ascética) pesimistas. Siguiendo este juego, el propio Onfray habla de una ontología blanca en Schopenhauer, esto es, la contemplación estética, la ética de la compasión y la negación ascética de la voluntad (Onfray, 2009: 263). Como ya he comentado, estas tesis están íntimamente ligadas a su metafísica, y el verdadero reto lo supone la eudemonología en tanto que pone entre paréntesis esa misma metafísica.

${ }^{11}$ De una manera sugerente, Neymeyr distingue cuatro conceptos de felicidad en Schopenhauer: como satisfacción de necesidades, como equilibrio de los deseos, como contemplación estética desinteresada y finalmente como renuncia ascética. La eudemonología estaría vinculada a las primeras concepciones de la felicidad, quedando la última en el ámbito de la ética (Neymeyr, 1996: 163-165).

12 Así también, Robert Zimmer señala la presencia de una teoría de la inteligencia social en la eudemonología de Schopenhauer (Zimmer, 2009: 47).

13 Esta relación entre Schopenhauer y Humboldt se la hizo notar su discípulo más agudo, Johann August Becker; Schopenhauer reconoce la coincidencia con W. von Humboldt en una carta a Becker en marzo de 1858. Véase el texto de Humboldt, publicado en 1851, mismo año que P/P, sobre Los límites de la acción del Estado (ed. de J. Abellán. Madrid: Tecnos, 1988): «El primer principio de esta parte de nuestra actual investigación deberá ser el siguiente: que el Estado se abstenga totalmente de velar por el bienestar positivo de los ciudadanos y se limite estrictamente a velar por su seguridad entre ellos mismos y frente a los enemigos del exterior, no restringiendo su libertad con vistas a ningún otro fin último» (Humboldt, 1988: 43). Schopenhauer conoció a los hermanos Humboldt en los salones berlineses (Zimmer, 2010: 146), y especial interés tuvo por las investigaciones naturales de Alexander. Tampoco hay que perder de vista la posible influencia del pensamiento político liberal del padre, Heinrich Floris, patricio burgués de Danzig, celoso de la independencia de la ciudad frente a Prusia, sobre su hijo (Safranski, 2001: 20). Para un sugerente análisis de esta tradición de pensamiento político liberal, véase John Gray en Liberalismo (trad. de Ma Teresa de Mucha. Madrid: Alianza, 1992, pp. 60-61), donde comenta el nacimiento del liberalismo alemán en la obra de Humboldt y su influencia en J. S. Mill.

${ }^{14}$ Véase Hübscher en su prólogo al volumen III del Nachlass (HN/MP, III, XI y ss.), así como en los comentarios sobre Gracián en el prólogo al volumen IV de la misma edición (HN/MP, IV, 1, p. x y ss.).
} 
de buscar una teoría de la felicidad o eudemonología y redacta un esbozo de un tratado sobre el honor $^{15}$, texto que encontrará su culminación en el apartado de los Aforismos dedicado a tal cuestión. Precisamente en ese momento (1826-1830), Schopenhauer había vuelto de uno de sus viajes a Italia y estaba preparando la traducción del Oráculo manual y arte de prudencia de Gracián (había empezado a aprender castellano a partir de 1825). La coincidencia es significativa, pues tanto el estilo como las ideas expresadas en los aforismos del jesuita aragonés tienen una fuerte influencia en el pensamiento de Schopenhauer.

No obstante, más allá de este momento crucial, la temática de una sabiduría sobre la felicidad mundana venía gestándose ya con anterioridad ${ }^{16}$. A mi juicio, esta temática está presente desde el inicio de la reflexión filosófica de Schopenhauer y es exigida por su propio planteamiento sobre el sufrimiento como la única constante de la vida humana, ya que al mismo tiempo que se abre la vía de la santidad y la redención mística-ascética, señala la necesidad y la insuficiencia de las máximas de prudencia mundana que se pueden encontrar en los ensayistas y moralistas para conseguir una vida feliz o, como lo expresa en esa época, una "consciencia mejor" (bessere Bewusstsein). Este tipo de conciencia se contrapondría a la consciencia temporal o empírica, junto con la que conformaría el yo o identidad personal.

En póstumos de 1814 encontramos que Schopenhauer reduce el concepto kantiano de razón práctica a un instinto y considera la ley moral como

un aspecto unilateral de la consciencia mejor tomado desde el punto de vista del instinto, consciencia que radica más allá de toda experiencia, por tanto, más allá de toda razón tanto teórica como práctica. [...] La consciencia mejor no es ni práctica ni teórica, porque éstas son meras divisiones de la razón ${ }^{17}$.

Así pues, la consciencia mejor es inalcanzable de un modo racional, señalándose ya la vía mística como la única factible para lograr ese nivel de consciencia, que presupone la superación del yo individual, más allá del principio de razón, y el distanciamiento respecto a la concupisciencia ${ }^{18}$. La consciencia mejor, de clara ascendencia platónica, nos haría pensar en la muerte con tranquila alegría e incluso con anhelo, pues en ella se conseguiría la liberación de lo corporal intuido como prisión.

Continuando con la cuestión central, en sus reflexiones de 1814 sobre el cuerpo como objeto inmediato del conocimiento a la vez que como fuente del sufrimiento de los humanos del que sólo se

\footnotetext{
${ }^{15} \mathrm{HN} / \mathrm{MP}, \mathrm{III}$, Adversaria, § 69, p. 472-496.

${ }^{16}$ Spierling apunta también en esta dirección (Spierling, 1994: 205).

${ }^{17}$ SCHOPENHAUER, A. HN/MP, I, § 35, p. 23.

${ }^{18}$ Safranski desarrolla esta teoría de la "consciencia mejor" en el capítulo 9 de su biografía sobre Schopenhauer.
} 
puede liberar mediante el conocimiento puro e intuitivo del genio y la ascética, Schopenhauer plantea el tema de la sabiduría de la vida o Lebensweisheit:

Entonces sólo la intuición proporciona felicidad, y todo sufrimiento se encuentra en el querer; pero, sin embargo, mientras viva el cuerpo, es imposible un no-querer completo, ya que está sometido a la ley de causalidad, pues todo influjo sobre él ocasiona necesariamente una volición: así pues, la verdadera sabiduría de la vida [Lebensweisheit] es que cada cual debería reflexionar sobre cuánto querer considera imprescindible, si no es capaz de alcanzar la más alta ascética, que es la muerte por inanición: cuanto más estrechos sean los límites de ese querer, más verdadero y libre es uno. Que después se satisfaga este querer limitado, pero que sobre todo no se permita ningún deseo y que pase la mayor parte del tiempo de su vida como sujeto cognoscente puro. Éste es el principio del cinismo [Kynismos], que en esta medida es incuestionable ${ }^{19}$.

En este texto, además de la concepción del conocimiento intuitivo (Anschauen) del genio como fuente de felicidad, Schopenhauer constata la dificultad de la vía ascética como negación y represión continua del cuerpo y precisamente ante esta constatación se presenta la noción de sabiduría vital como recurso último para lograr una vida feliz: esta sabiduría vital se definiría, pues, por un conocimiento de uno mismo y sus limitaciones, una reflexión sobre las necesidades que se requiere satisfacer, un control de los propios deseos y por un intento de dedicarse al conocimiento puro.

Si esta noción de sabiduría vital es efectivamente atribuible o no a los cínicos antiguos, es una cuestión secundaria, en la medida en que éstos suponen para Schopenhauer un modelo fehaciente de su concepción de la vida mundana, frente, por ejemplo, al estoicismo. Éstos, por su parte, no tendrían una moral en el sentido fuerte de Schopenhauer, sino que, en la medida en que hacen de la razón y de la adecuación a ésta y a la naturaleza los criterios de la vida moral, convertirían esta disciplina filosófica en una «indicación para la vida racional (en el sentido estricto de la palabra, no para la vida virtuosa) $\rangle^{20}$. La distinción entre racionalidad y virtud, y su incompatibilidad dentro del marco de la moral de la compasión de Schopenhauer, desplazan al estoicismo del ámbito de la moral stricto sensu al de esa nueva disciplina de la sabiduría de la vida. Algo semejante ocurrirá con la ética aristotélica: desde la perspectiva schopenhaueriana será difícilmente asumible en el ámbito moral, pero será de gran ayuda para el desarrollo de sus ideas sobre la sabiduría vital ${ }^{21}$.

En definitiva, el proyecto de la sabiduría de la vida se nutre de la estrategia general de Schopenhauer de considerar los conceptos centrales de su filosofía de modo negativo: así como ocurre con los conceptos de libertad o derecho, también el de felicidad es definido como la ausencia de

\footnotetext{
${ }^{19}$ SCHOPENHAUER, A. HN/MP, I, § 220, p. 127.

${ }^{20} \mathrm{HN} / \mathrm{MP}, \mathrm{I}, \S 358$, p. 223.

${ }^{21} \mathrm{HN} / \mathrm{MP}, \mathrm{I}, \S 132$, p. 81-82.
} 
sufrimiento, la realidad positiva que encontraríamos en el mundo. Y esta definición de felicidad no es ajena al proyecto general de El mundo como voluntad y representación, pues allí se define en el $\S 58$, con lo que podemos pensar que, aunque en su obra magna no se desarrolla una eudemonología, se abre la posibilidad e incluso el esbozo para su desarrollo posterior.

Más aún, en el párrafo dedicado al problema de la libertad ${ }^{22}$, como ya apuntamos, tras plantear la distinción entre tipos de carácter, Schopenhauer reconoce que el carácter adquirido como autoconocimiento completo a partir de sus propias experiencias y acciones es el mejor medio de superar el descontento con uno mismo, el más amargo de los males. Del mismo modo, en El mundo se recogen muchas de las reflexiones de los manuscritos anteriores respecto al problema de una sabiduría mundana y sus críticas y comentarios a las escuelas antiguas de pensamiento ético, temas que van a emerger de nuevo en los Aforismos bajo la perspectiva de una teoría de la vida feliz ${ }^{23}$.

En este sentido, en un texto de 1826 de los manuscritos, podemos apreciar cómo va tomando forma ese proyecto de una eudemonología; ahora bien, teniendo en cuenta un modo de proceder propio y que tiene que cumplir al menos dos condiciones:

La sabiduría de la vida como doctrina sería sinónimo aproximadamente de eudemónica. Debería enseñar a vivir felizmente en la medida de lo posible y solventar esta tarea bajo dos limitaciones: sin llegar a ser meditación estoica ni maquiavelismo. [...] El ámbito de la eudemónica se encuentra por tanto entre el del estoico y el del maquiavelismo, considerando ambos extremos como atajos a los que se renuncia para llegar a la meta: la eudemónica enseña cómo se puede vivir felizmente, sin una gran renuncia y auto-superación, y sin considerar a los demás como nada más que posibles medios para sus fines ${ }^{24}$.

Por tanto, la eudemónica o sabiduría de la vida ha de evitar la Escila del sabio estoico demasiado rigorista para el ser humano medio y la Caribdis del maquiavelismo, que según Schopenhauer supone sacrificar la felicidad de los demás para conseguir la propia. La búsqueda de un camino intermedio va a marcar la reflexión de Schopenhauer; los referentes tanto clásicos como modernos son abundantes, pero él mismo dice enfrentarse a una tarea sin precedentes, pues tendría que organizar bajo distintas rúbricas un amplio conjunto de reglas y consejos sobre temas diversos.

Además, si nos centramos en la cuestión de lo social, los manuscritos ofrecen otro documento de gran interés para entender el largo proceso que lleva a Schopenhauer a la redacción de los Parerga.

\footnotetext{
${ }^{22}$ Cf. WWV/MVR, I, § 55 .

${ }^{23}$ Ingenkamp también indica que en la presentación de la sabiduría de la vida la separación no es tan radical como la presenta Schopenhauer en la introducción a estos aforismos (Ingenkamp, 2006: 80). Es más, indica que un nexo a tener en cuenta es el de la corporalidad, aunque a mi juicio más crucial es en este contexto la teoría del carácter adquirido. También apunta que los valores de fondo de la eudemonología serían los mismos que en toda su filosofía, aunque formulados de un modo empírico (Ingenkamp, 2006: 89).

${ }^{24}$ SCHOPENHAUER, A. HN/MP, III, Foliant II, §124, 268-269.
} 
Ese documento es un «Esbozo de un tratado sobre el honor». En este esbozo de 1828 ya se puede apreciar la crítica a los diversos tipos de honor que plantea Schopenhauer (el honor burocrático del funcionario, el sexual, el burgués o civil y el caballeresco), y así como la rúbrica "lo que uno es" permitía reflexionar sobre la noción de personalidad como desarrollo de la de carácter adquirido (con toda la complejidad de ese desarrollo, especialmente asumiendo nociones de raigambre aristotélica como la de autarquía), la crítica a la noción de honor en tanto que figura principal del mundo social de la representación muestra bien a las claras la concepción radicalmente negativa de la vida social por parte de Schopenhauer. Del mismo modo que el mundo puede contemplarse como voluntad y como representación, la vida individual tiene un núcleo, la personalidad, que es el santuario de la felicidad, y un ámbito representativo, una vertiente social, que es considerada como fuente de infelicidad: la representación en ambos casos (ontológico y eudemonológico) es equivalente a inautenticidad.

La permeabilidad entre la esfera de la representación social y la personalidad queda excluida por principio: para Schopenhauer, cualquier atisbo de una posible construcción social de la personalidad o de una noción representativa de la identidad social sería equivalente a una falta de carácter, a una debilidad frente al modelo de la autarquía y el primer paso hacia una vida malograda. En cierto modo, esta radical fobia hacia lo social como ámbito de representación de los individuos condiciona una teoría de lo político que plantea como principal misión del Estado la de la protección de los individuos ante sus conciudadanos.

Hasta aquí he querido presentar los Aforismos sobre la sabiduría de la vida de 1851 como el fruto de un largo desarrollo intrínseco a la obra de Schopenhauer desde sus inicios. En lo que sigue, quisiera exponer críticamente, no ya el proceso de génesis de estos textos, sino la doble consideración de la sociedad desde el punto de vista de la representación y la voluntad.

\section{La sociedad como representación: el absurdo del honor}

Nos enfrentamos a continuación con la visión schopenhaueriana de la vida social como tal y, en especial, la representación de un individuo ante los demás. Este tema remite a la distinción ontológica básica entre el mundo como voluntad y el mundo como representación: en cierto modo, se puede pensar que la sociedad, en tanto que conjunto de individuos entrelazados en múltiples relaciones entre sí, puede abordarse desde la perspectiva representativa, epistémica, atendiendo a juicios y valoraciones, a la vez que también puede contemplarse como un sistema de fuerzas en acción para el logro de finalidades conscientes e inconscientes para los individuos que protagonizan esa vida social.

Si adoptamos la primera perspectiva (la segunda se abordará en el siguiente apartado), como hace Schopenhauer en el capítulo IV de los Aforismos, el primer obstáculo en el camino de la felicidad 
es la opinión ajena, contra la cual advierte Schopenhauer (de la mano de Horacio) tanto cuando es positiva como cuando es negativa. La argumentación de Schopenhauer recurre al plano fenomenológico; nuestra representación sólo es real en la conciencia ajena, en la que se entreteje con conceptos e imágenes a las que somos asociados, pero que poco o nada tendrían que ver con nuestra personalidad vivida por nosotros:

El lugar de lo que somos para otros es la consciencia ajena [fremde Bewusstseyn]: es la representación bajo la que aparecemos en ella junto a conceptos que se le aplican a ésta. Pero esto es algo que no está presente ante nosotros de forma inmediata, sino que lo está de forma mediata, en tanto que a través de ella se determina el comportamiento de los demás hacia nosotros. Y esto mismo sólo entra en consideración en la medida en que tiene influencia sobre algo a través de lo cual pueda modificarse lo que somos en $y$ para nosotros mismos ${ }^{25}$.

Este texto de Schopenhauer muestra de nuevo la fuerza que tiene la distinción ontológica entre voluntad y representación también en los Aforismos; en este caso, dicha dualidad se articula como el ser para sí y el aparecer para otros. Sin embargo, se admite la posibilidad de una comunicación e influencia entre los dos ámbitos. Si bien la recomendación de Schopenhauer es la máxima indiferencia posible ante la opinión y el juicio ajenos, se plantea una vía de influencia bajo dos supuestos: en primer lugar, el efecto causal de esas representaciones sobre la conducta ajena respecto a nosotros y, en segundo lugar, que esa conducta afecte a algo que pueda modificar nuestro modo de ser para nosotros mismos, en terminología del propio Schopenhauer.

En cuanto al primer supuesto, cabe señalar que se trata de un supuesto idealista en tanto que explica la acción humana como el resultado de unas valoraciones u opiniones conscientes, dejando de lado la posibilidad de motivaciones inconscientes (aunque el propio Schopenhauer lo plantee en otro lugar), o la posibilidad de invertir el esquema causal, de modo que las valoraciones y representaciones no sean más que el resultado de unas relaciones sociales condicionadas por otros factores, o sintetizar ambas perspectivas (idealista y materialista). Pero además de este primer supuesto sobre la acción social, Schopenhauer deja entrever la posibilidad de una influencia del juicio ajeno si el comportamiento resultante modifica en algún sentido lo que somos para nosotros. A primera vista, podemos pensar que se trata de una posible inconsecuencia de la articulación entre metafísica, ética y eudemonología, pues Schopenhauer ha insistido vehementemente en la imposibilidad de modificar nuestro carácter y en el innatismo del carácter empírico.

No obstante, hemos de tener en cuenta de nuevo el concepto de carácter adquirido como conocimiento de sí para dotar de sentido esta reflexión sobre la influencia del juicio ajeno sobre

\footnotetext{
${ }^{25}$ SCHOPENHAUER, A. P/P, I, p. 351.
} 
nuestra personalidad: dicha valoración ajena puede modificar nuestro ser para nosotros no en sentido ontológico, sino en el sentido de que puede iluminar nuestra forma de comprendernos a nosotros mismos, de modo que la opinión de los otros puede tener cierta fuerza performativa siempre y cuando influya sobre nuestro propio autoconocimiento. En el esquema de Schopenhauer esta performatividad está limitada por la distinción ontológica entre voluntad y representación (la voluntad, a lo sumo, se expresa en el plano de la representación, pero lo que ocurre en éste no influiría en aquélla), y también por la consiguiente teoría del carácter, según la cual el carácter empírico es expresión inmutable e innata del carácter inteligible o voluntad, de tal modo que sólo el carácter adquirido o conocimiento de sí hace posible la transformación y variación de las acciones de un mismo individuo ${ }^{26}$.

Ahora bien, hay que destacar lo siguiente: Schopenhauer ha dividido los bienes de la eudemonología entre ser, tener y representar, pero en algún momento llega a identificar los dos primeros, el ser y el tener, como la fuente de la felicidad frente al ámbito de la representación:

En cualquier caso, se le indica un recurso miserable a aquel que no encuentra su felicidad en las dos clases de bienes ya tratados y tiene que buscarla en esta tercera, esto es, no en lo que es realmente, sino en lo que es en la representación ajena. Porque la base de nuestra esencia en general, y en consecuencia de nuestra felicidad, es nuestra naturaleza animal ${ }^{27}$.

Por una parte, se muestra la propiedad (el tener) como una extensión de la personalidad, del ser del individuo, concepción que emergerá en pleno desarrollo en la teoría política de Schopenhauer. Pero, por otra, y esto es más importante ahora, en este texto se destaca la referencia a la naturaleza animal del ser humano, lo que es un indicio de la posición cínica (en sentido clásico) de Schopenhauer y que supone la asunción de un punto de vista crítico con los valores sociales, en concreto, el honor, el orgullo, la vanidad y la fama: la felicidad humana no es muy distinta de la animal y se basaría en la satisfacción de unas mismas necesidades. Por ejemplo, la diferencia entre orgullo y vanidad es establecida por Schopenhauer de acuerdo con el criterio dualista interior/exterior o individuo/sociedad, de modo que esto implica una valoración negativa de la vanidad en comparación con el orgullo:

En consecuencia, el orgullo [Stolz] es la alta estima de sí mismo que surge del interior, y por tanto directa; por el contrario, la vanidad [Eitelkeit] es el ansia por conseguirla desde el exterior, esto es, indirectamente ${ }^{28}$.

\footnotetext{
${ }^{26}$ Véase también sobre la relación del honor con este tema de la representación Lütkehaus, 2006, p. 97.

${ }^{27}$ SCHOPENHAUER, A. P/P, I, 351.

${ }^{28}$ SCHOPENHAUER, A. P/P, I, 356.
} 
En cierto modo, Schopenhauer elogia el sentimiento del orgullo en tanto que surge de la consciencia de posesión de un atributo bien valorado, criticando la falsa modestia y defendiendo la necesidad de reconocer los propios méritos; pero a la vez aprovecha esta digresión sobre el orgullo para mostrar su nominalismo radical y su anticolectivismo, aspectos patentes en su concepción de la historia como disciplina, especialmente en WWV/MVR, II, § 38. En este caso el punto de ataque es el orgullo nacional, la soberbia y la alta estima hacia uno mismo en tanto que miembro de una nación; para Schopenhauer, este sentimiento de orgullo colectivo, vinculado al nacionalismo, es índice de cierta falta de propiedades individuales de las que sentirse orgulloso: el orgullo por formar parte del colectivo revela la vacuidad de los individuos particulares.

Esta tesis tiene una fuerte connotación polémica tanto filosófica como políticamente: filosóficamente, contra el nacionalismo teorizado por su maestro Fichte; políticamente, Schopenhauer aprovecha para atacar los movimientos demócratas de su momento histórico. Para realizar este segundo paso, se produce una asimetría importante: respecto de los colectivos no cabe el sentimiento de orgullo positivo, pero sí el de crítica y desprecio, es decir, no se les puede atribuir cualidades positivas, pero sí negativas, con lo cual el nominalismo schopenhaueriano, según el cual el refugio en la abstracción colectiva es resultado del vacío individual, es matizado siempre y cuando al colectivo se le atribuyan propiedades negativas. Éste es el ejemplo de la valoración que hace Schopenhauer de los ingleses frente a los alemanes, comparación que muestra esta inconsistencia de asimetría negativa, un cierto patriotismo de Schopenhauer y también su posición política anti-democrática:

\begin{abstract}
Por ejemplo, por eso, se encontrará entre cincuenta ingleses a duras penas más de uno que esté de acuerdo, cuando se habla de la estúpida y degradante mojigatería de su nación con el desprecio que se merece. Los alemanes están libres del orgullo nacional y proporcionan así una muestra de su famosa honestidad; al contrario que aquellos de entre ellos que fingen un tal orgullo y lo aparentan de un modo ridículo, como hacen casi siempre los "hermanos alemanes" y los demócratas, que agasajan al pueblo para corromperlo. [...] Por demás, la individualidad predomina de largo sobre la nacionalidad y en una persona en concreto aquélla merece mil veces más consideración que ésta. Nunca se podrá ensalzar mucho el carácter nacional sinceramente, puesto que trata de la cantidad. Más bien la limitación, la absurdidad y la maldad humanas aparecen en todos los países bajo una forma particular y a ésta se le llama carácter nacional ${ }^{29}$.
\end{abstract}

Así pues, la no admisión de atribuciones colectivas y su nominalismo anticolectivista, encuentra un límite claro en su pesimismo: los únicos predicados legítimos para los colectivos humanos son los negativos, de modo que la única forma de hablar del carácter nacional es por los defectos de esas colectividades. Pero además, este texto muestra la desconfianza radical de

\footnotetext{
${ }^{29}$ SCHOPENHAUER, A. P/P, I, 358.
} 
Schopenhauer hacia los movimientos democráticos por entender que no son más que demagógicos y que se aprovechan de la ignorancia popular.

Ahora bien, aunque la definición del orgullo permite extraer estas consideraciones sociológicas y en cierta medida políticas, en los Aforismos hay que destacar especialmente la crítica del honor, crítica que está esbozada ya en los fragmentos póstumos de los años 1820-1830 y que constituyen un esbozo ensayístico sobre el honor. ${ }^{30}$ Nuestra intención es atender a las implicaciones sociológicas de las reflexiones sobre el honor, que parten de la siguiente definición:

Objetivamente el honor es la opinión de otros sobre nuestro valor y subjetivamente nuestro temor ante esta opinión. A título de esto último tiene a menudo un efecto muy saludable, aunque en modo alguno moralmente puro en el hombre de honor. [...] El ser humano por sí sólo es capaz de muy poco y es un Robinson abandonado: solo en comunidad con los otros es y puede muchas $\operatorname{cosas}^{31}$.

En primer lugar, hay que señalar la doble perspectiva, objetiva y subjetiva, de la que se sirve Schopenhauer en este texto: según la objetiva, el honor no sería sino la valoración ajena acerca de nosotros, mientras que la subjetiva consistiría en el temor que le correspondería por parte de los individuos particulares. Esto revela que el honor supone en cierto sentido un medio de control y censura social mediante el temor. Pero además, en segundo lugar, cabe observar que ese efecto del temor sobre los individuos en absoluto posee un carácter moral, esto es, únicamente derivado de la compasión, sino que más bien tiene un efecto de tipo sociológico (respeto y contención en las relaciones sociales) o incluso eudemonológico, a saber, facilita el logro de la tranquilidad de ánimo y la satisfacción que forman parte de la felicidad.

Y, por último, el honor está ligado a la vergüenza como valor social. Si tiene este efecto eudemonológico y sociológico es porque Schopenhauer reconoce la necesidad de la vida comunitaria para el ser humano, pese a ser un crítico desconfiado y radical de la vida social que considera que únicamente en soledad se puede conseguir el objetivo de su eudemonología, en definitiva, la felicidad como fenómeno negativo, la máxima reducción posible de dolor. Ahora bien, es importante insistir en este último punto, puesto que Schopenhauer afirma que el individuo que vive en comunidad es y puede hacer muchas más cosas que solo (nur in der Gemeinschaft mit den andern ist und vermag er viel), está admitiendo las virtualidades y potencialidades que se generan en sociedad y que la vida retirada no permite desarrollar en un doble sentido, a saber, en aquello que uno es, aquello que lo constituye, y en aquello que es capaz de hacer, de sus capacidades y habilidades.

\footnotetext{
${ }^{30}$ HN/MP, III. A juicio de Lütkehaus en este esbozo hay más ideas incluso que en el texto publicado en PP (Lütkehaus, 2006: 95).

${ }^{31}$ SCHOPENHAUER, A. P/P, I, p. 359-360.
} 
Bajo este punto de vista el honor se presenta como un fenómeno propio de la eudemonología o incluso de la teoría de la sociedad de Schopenhauer, tanto por su propia definición como por sus efectos sobre el sujeto afectado, pero no hemos de olvidar la conexión, aunque él trate de negarla en el prólogo a los Aforismos, entre la eudemonología y el resto de su sistema (metafísica, ética, estética). En concreto, el asunto del honor está estrechamente ligado a un aspecto de su ontología del que ya nos hemos ocupado repetidamente, a saber, la teoría del carácter:

Pero el honor descansa siempre, en última instancia, sobre la convicción en la inmutabilidad del carácter moral, por la cual una única mala acción garantiza la misma índole moral para todas las acciones siguientes, tan pronto como se den circunstancias semejantes $^{32}$.

Así pues, se plantea aquí la posibilidad de un vínculo de fundamentación entre eudemonología y ontología, pero no se trata sólo de una problemática sobre la estabilidad del sistema o el acierto de la visión sobre su propia filosofía por parte de Schopenhauer, sino que implica una tensión en el interior del plano eudemonológico: el honor se puede perder con una sola acción que provoque una mala opinión de los demás, porque una mala acción supone que las siguientes serán de la misma naturaleza, si se dan las mismas circunstancias. Esa acción, en definitiva, habría revelado el carácter de fondo de ese individuo y el honor no se puede recuperar; ésta es la consecuencia de la teoría ontológica del carácter aplicada a la cuestión del honor. La sanción social (o penal) no podría nunca restablecer la imagen pública, del mismo modo que no puede modificar la esencia del carácter empírico del individuo (reflejo del carácter inteligible o voluntad), por mucho que éste haya logrado un mayor conocimiento de sí (carácter adquirido).

Esto último se aplica especialmente a uno de los tipos de honor a los que se dedica Schopenhauer, el honor civil. Junto a éste trata también del honor de cargo, el honor sexual, el caballeresco y el honor nacional. Para nuestro propósito son de interés crucial el primero, el honor civil, y el penúltimo, el honor caballeresco (en pro del argumento renunciaremos a hacer algunas observaciones sobre los otros tipos).

Según el propio Schopenhauer, el honor cuyo ámbito de acción es mayor es el primer tipo, el honor civil, puesto que se podría aplicar a cualquier individuo en tanto que miembro de una sociedad y súbdito de un sistema de derecho:

El honor civil [bürgerliche Ehre] tiene la esfera más amplia: éste consiste en la presuposición de que respetamos incondicionalmente los derechos de todos $\mathrm{y}$, por

\footnotetext{
${ }^{32}$ SCHOPENHAUER, A. P/P, I, p. 361.
} 
tanto, nunca nos serviremos de medios injustos o no permitidos legalmente en nuestro provecho. Es la condición para la participación en cualquier relación pacífica ${ }^{33}$.

De este modo, el honor civil se define como el respeto por los derechos de los demás ciudadanos, constituyendo así el nivel cero de la sociabilidad, su condición de posibilidad, sin la cual no se podría tomar parte en eso que Schopenhauer ha llamado «relación pacífica [friedlicher Verkehr]». Siendo así, la teoría de la sociedad requiere de este sentimiento de honor civil e implica también que la teoría del derecho necesita de este respeto mutuo entre los ciudadanos para mantener la estabilidad social: es en este sentido que lo he denominado el nivel cero de la sociabilidad, ya que es este miedo subjetivo a la opinión de los demás, el honor, lo que pone las bases para el respeto por los demás, así como supone un acicate para la sociabilidad de los individuos (más allá de las necesidades y posibilidades que no desarrollaría en la vida retirada).

En consecuencia, se puede apreciar que la argumentación de Schopenhauer sobre el honor viene a matizar su concepción tan negativa de la vida social, reconociendo el valor indirecto que tiene en tanto que opinión ajena que puede influir sobre nosotros:

El valor del honor es sólo mediato. [...] Puesto que, en el estado civilizado [im civilisierten Zustande], sólo debemos a la sociedad la propiedad y la seguridad, también necesitamos a los otros en cualquier empresa y tenemos que ganarnos su confianza para que se embarquen con nosotros, así su opinión sobre nosotros nos es de gran valor, aunque sólo mediato: no le puedo reconocer un valor inmediato ${ }^{34}$.

Como consecuencia de vivir en ese estado civilizado de tipo burgués, Schopenhauer reconoce que los dos valores sociales de mayor rango en él son la propiedad y la seguridad, valores típicamente burgueses, pero va un paso más allá y considera no sólo que la sociedad los tiene que garantizar mediante la institución del Estado (presente entre líneas en el texto citado), sino también que esa sociedad civilizada burguesa promueve eminentemente las relaciones mercantiles entre los ciudadanos, de tal modo que el valor del honor es mediato en este sentido pragmático y comercial: el honor influye sobre los individuos en la medida en que les interesa tener una buena imagen pública con el fin de ganarse la confianza de los demás e implicarlos en sus empresas y relaciones socio-económicas, como se desprende de la referencia a la propiedad y la seguridad.

También es importante atender al honor caballeresco, cuya crítica aporta luz sobre la teoría de la sociedad y la filosofía política latente en estos Aforismos. En primer lugar, abordaremos las características principales de este tipo de honor, para luego, estableciendo su clara oposición al honor civil o burgués (justificado por Schopenhauer), analizar los diferentes argumentos mediante los que lo

\footnotetext{
${ }^{33}$ SCHOPENHAUER, A. P/P, I, p. 360-361.

${ }^{34}$ SCHOPENHAUER, A. P/P, I, p. 362-363.
} 
critica y que revelan una concepción (que casi podría calificarse de síntesis liberal-conservadora) de la sociedad.

Si pasamos a esta cuestión del honor caballeresco, éste se regiría [1] no por el principio según el cual el honor depende de la opinión de otros sobre uno mismo, como había definido Schopenhauer, sino de las manifestaciones y afirmaciones sobre uno, independientemente de si el que las enuncia cree en ellas o están o no fundamentadas. De este modo, por una parte, la retractación de una afirmación ofensiva sería suficiente para evitar el conflicto, haya cambiado o no la opinión privada del sujeto que la enunció; pero, por otra, la insinuación más infundada, como un rumor, es suficiente para provocar una disputa o un duelo. Además, este honor [2] se fundaría en un principio de pasividad, en tanto que su vulneración depende no tanto de las acciones que se llevan a cabo cuanto de aquello que le ocurre, le pasa o sufre el sujeto, pasividad que sería complementaría de la idea de la presunción de culpabilidad, esto es, hay que demostrar la propia inocencia, se parte de la culpabilidad como de un hecho que le acontece al individuo, por la causa que fuera, bien un rumor, bien una acusación explícita. En consecuencia, [3] el modo de dirimir estas disputas es el duelo y [4] la forma de expresar el propio honor caballeresco es la arrogancia del insulto y la puesta en duda del honor de los demás. Esta lógica se completa con la idea de que [5] la instancia a la que se apela es el derecho del más fuerte, el cual no es derecho alguno, argumenta Schopenhauer, y [6] recurre como forma de crédito y garantía a la palabra de honor, frente a la escrupulosidad jurídica del honor civil que articula sus relaciones mediante el derecho.

El propio Schopenhauer, tras ofrecer estos seis aspectos definitorios del honor caballeresco, ofrece una serie de argumentos en contra de su validez (a-e):

a) Uno de los modos de criticar esta forma de honor es mediante un argumento de tipo culturalista; esto es, en otras sociedades sólo se conocería el primer tipo de honor, el honor civil, siendo el caballeresco propio de una sociedad feudal, cuyo fundamento habría dejado de existir:

Todos ellos no conocen otro honor que el analizado en primer lugar [el honor civil]. Entre todos ellos el hombre vale por lo que manifieste su acción y su omisión, pero no por lo que a alguna lengua suelta le apetezca decir de él ${ }^{35}$.

El soporte de esta afirmación tiene que ver, como tantas otras argumentaciones de los Aforismos, con el legado clásico: Platón, el Sócrates de Diógenes Laercio, Séneca o alguna anécdota de Diógenes de Sínope son las fuentes con las que Schopenhauer muestra que hay alternativas factibles y filosóficamente justificadas al point d'honneur caballeresco. Ahora bien, a este argumento de tipo

\footnotetext{
${ }^{35}$ SCHOPENHAUER, A. P/P, I, p. 372-373.
} 
culturalista, tomando como referencia una determinada visión del mundo clásico y helenístico, adjunta Schopenhauer otras réplicas como la siguiente:

b) Una crítica genealógico-histórica que incide en la falta de fundamentación antropológica del honor caballeresco; éste no tendría en cuenta la verdadera naturaleza humana, basada en el dualismo intelecto-voluntad y en la ciega primacía de la segunda (aspecto que reaparecerá en el argumento propiamente antropológico [e]), sino que sería un subproducto de una época de sumisión y falta de libertad de pensamiento, aspecto que aleja a Schopenhauer del romanticismo medievalista tan de moda en su época ${ }^{36}$ :

El principio del honor caballeresco en modo alguno puede ser un principio originario fundado en la naturaleza humana misma. Es un principio artificial y su origen no es difícil de encontrar. Es obviamente un vástago de aquella época en la que los puños se usaban más que las cabezas, y los párrocos tenían a la razón encadenada, esto es, de la estimada Edad Media y su nobleza ${ }^{37}$.

c) En la misma línea que los dos argumentos anteriores, otra vía de crítica al honor caballeresco tiene que ver con el mecanismo de cohesión social que implica el desarrollo de esta forma de honor. En este sentido, se trata ahora de un argumento psico-sociológico, según el cual, el honor civil fomenta las relaciones pacíficas y la confianza entre conciudadanos, mientras que el honor caballeresco tiende a articular las relaciones sociales basándose en sentimientos de temor y odio, factores de cohesión social que no permiten una estabilidad a largo plazo:

El núcleo del asunto es el siguiente: así como el honor civil, que tiene como objetivo la relación pacífica con otros, consiste en su opinión sobre nosotros de que merecemos confianza completa, porque respetamos incondicionalmente los derechos de cada cual, el honor caballeresco consiste en que los otros opinen que somos de temer, porque estamos dispuestos a defender incondicionalmente nuestros derechos ${ }^{38}$.

Este argumento, pues, concierne al contenido psicológico de la creencia que se quiere provocar en los otros y en las consiguientes formas de sociabilidad: la confianza y el respeto propios del honor civil, que son defendidos aquí por Schopenhauer como los elementos de cohesión social propios de una sociedad estable, frente al temor y la intransigencia, propios del honor caballeresco.

En cuarto lugar, d) encontraríamos una crítica político-jurídica del honor caballeresco: la institución del Estado moderno convierte en un absurdo jurídico la defensa de algo así como un honor

\footnotetext{
${ }^{36}$ Lütkehaus ha insistido en que estas notas sobre el honor muestran a un Schopenhauer alejado del romanticismo y mucho más afín al espíritu ilustrado. En esta oposición emergería la figura de Fichte, quien habría dignificado el concepto de honor, de manera que esta crítica al honor sea también indirectamente una polémica con Fichte (Lütkehaus, 2006: 93-94).

${ }^{37}$ SCHOPENHAUER, A. P/P, I, p. 375.

${ }^{38}$ SCHOPENHAUER, A. P/P, I, p. 376.
} 
caballeresco, de tipo privado, y que sólo acepta la fuerza como medio de dirimir sus lances. Con Max Weber, Schopenhauer podría decir que el monopolio de la violencia legítima en un territorio determinado es propio del Estado moderno, de manera que deslegitima y proscribe cualquier forma de actuación como la prevista en el honor caballeresco, concretamente, en el duelo:

Pero en el estado de civilización, en la que el Estado ha asumido la protección de nuestra persona y nuestra propiedad, ya no encuentra ninguna aplicación, y se mantiene ahí, como los fuertes y las torres de vigilancia de la época del derecho del más fuerte, inservibles y abandonados, entre campos labrados y dinámicas carreteras, o incluso vías de ferrocarril ${ }^{39}$.

Es significativo que se mencione como la principal finalidad del Estado la defensa y protección no sólo de la persona física del súbdito o del ciudadano (dejemos abierta esta cuestión), sino también de la propiedad, valor típicamente burgués y liberal, siendo el liberalismo una perspectiva política que tendrá su influencia en el pensamiento socio-político explícito de Schopenhauer ${ }^{40}$. Bajo este punto de vista, el honor caballeresco sería un vestigio o incluso un obstáculo para el desarrollo de la política estatal y su administración del derecho y la justicia.

Ahondando en esta misma perspectiva, Schopenhauer insiste en el peligro del conflicto civil, de la aparición de un Estado dentro del Estado, al modo de una red de articulación de derechos y administración de servicios que ponga en peligro la legitimación y el sentido del Estado burgués (con el modelo del honor civil) que está planteando como modelo teórico en estos textos de los Aforismos:

Además es escandaloso que aquel principio y su absurdo código funde un Estado dentro del Estado que, no reconociendo otro derecho que el derecho del más fuerte, tiraniza mediante dicho código a las clases a él sometidas ${ }^{41}$.

De acuerdo con este texto, la erradicación del honor caballeresco tendría que empezar con la reeducación de las clases superiores (piénsese en la nobleza rural prusiana del siglo XIX, los Junker), de acuerdo con los principios de la burguesía mercantil, que en definitiva son los principios que parece defender Schopenhauer aquí. En algunos textos, Schopenhauer da a entender que sobre las clases superiores se produce una fuerte presión social, pues se espera que se rijan por ese código caballeresco, produciendo una situación de angustia que podría salvarse mediante la conversión de esta clase social en clase burguesa propietaria (aquí podemos encontrar en mantillas algo así como una teoría del cambio social). Además, por otra parte, es evidente la crítica al derecho del más fuerte como una forma

\footnotetext{
${ }^{39}$ SCHOPENHAUER, A. P/P, I, p. 376.

${ }^{40}$ Ver, por ejemplo, argumentaciones como las de Wolf, 1997 o Hopf, 1982.

${ }^{41}$ SCHOPENHAUER, A. P/P, I, p. 383.
} 
espúrea de derecho: el Faustrecht o derecho del más fuerte no sería más que el reinado de la brutalidad, y más bien sería un Faustehre, esto es, un honor del puño o de la fuerza, y en modo alguno una forma de derecho ${ }^{42}$. Es precisamente la crítica a la concepción naturalista del derecho, en el sentido de derecho como poder o fuerza, lo que está en la base de la oposición al honor caballeresco.

Pero en el nivel de la fundamentación no sólo encontramos su teoría del derecho, a la que habremos de volver, sino también, como se ha apuntado supra, e) una determinada visión de la naturaleza humana. Éste sería el quinto argumento en contra del honor caballeresco:

Pero el honor caballeresco [...] se ha ensalzado hasta devenir una sobreestimación del valor de la propia persona completamente inadecuado a la naturaleza, constitución y destino del ser humano, al punto que se eleva hasta una suerte de santidad y en consecuencia encuentra insuficiente la pena del Estado por los pequeños agravios del mismo, de tal manera que este tipo de honor se hace cargo de la pena y, por cierto, siempre sobre el cuerpo y la vida del ofensor ${ }^{43}$.

La crítica de Schopenhauer consiste en la denuncia de la beatificación del ser humano, un optimismo antropológico que tendría un corolario difícil de aceptar en el ámbito de la teoría penal: el castigo estatal sería insuficiente, la institución del Estado no tendría legitimidad para establecer la pena de ese ser bueno por naturaleza, arrogándose ese privilegio el propio honor caballeresco. En definitiva, esta deslegitimación de la función penal del Estado está fundada en una crítica de carácter antropológico, puesto que según Schopenhauer:

Incluso una mirada imparcial a la naturaleza del ser humano nos enseña que el golpear le es tan natural como el morder a las fieras o el embestir a los astados: es precisamente un animal que golpea [ein prügelndes Tier $]^{44}$.

Esta definición del ser humano como animal que golpea es un elemento a tener en cuenta en la articulación de su pesimismo existencial y su concepción de la sociedad como colectividad en la que la violencia potencial latente requiere de un férreo control del Estado. Como ya había ensayado en su escrito sobre el fundamento de la moral, esta definición del ser humano conduce a una crítica del concepto kantiano de dignidad humana: ésta no sería más que una superstición procedente del pensamiento religioso que nos considera criaturas divinas, pero el paradigma de Schopenhauer se encuentra en las antípodas de éste, pues justifica plenamente el castigo físico sobre quien no atienda a razones aduciendo la naturaleza animal y semi-diabólica de los humanos.

\footnotetext{
${ }^{42}$ A propósito de esta crítica del honor caballeresco, Schopenhauer se distancia de su admirado en otros asuntos Rousseau por haberse dejado llevar por la superstición del honor caballeresco en el Emilio.

${ }^{43}$ SCHOPENHAUER, A. P/P, I, p. 377.

${ }^{44}$ SCHOPENHAUER, A. P/P, I, p. 381.
} 
De acuerdo con estas críticas al honor caballeresco (a-e), observamos que muchas de ellas, como este último caso, se apoyan en supuestos de tipo metafísico propios del sistema desarrollado en El mundo como voluntad y representación. Esto supone una carga ontológica en la argumentación propiamente eudemonológica, en tanto que introduce unas tesis metafísicas no fundadas en la experiencia cotidiana en un discurso que pretende partir de ésta, como se planteaba en el prólogo de los Aforismos, y evitar el "escándalo metafísico" de la voluntad.

Ahora bien, esto ocurre con algunas otras temáticas desarrolladas en la eudemonología, pero la crítica del honor caballeresco nos permite establecer un vínculo entre esa fundamentación metafísica y las consideraciones sociológicas que hacen más inteligibles sus tesis sobre política. Es en este sentido que Schopenhauer considera que la filosofía como discurso racional no puede dejar de lado la crítica al honor caballeresco, por todos los argumentos que se han presentado aquí, pero especialmente por un imperativo exigido por su eudemonología: el ideal de autarquía está vinculado con la idea de felicidad y de auto-satisfacción, con una satisfacción y aprecio de sí que ha de servir como antídoto frente a la lógica de la ofensa y la injuria propia del honor caballeresco.

A continuación, dejaremos de lado la cuestión de la sociedad como ámbito de representación y nos ocuparemos de la sociedad en tanto que ámbito de manifestación, expresión y lucha de la voluntad consigo misma.

\section{La sociedad como voluntad: cohesión y coacción social}

En la construcción de la eudemonología, Schopenhauer no sólo va a considerar la sociedad como conjunto de representaciones, como un ámbito en el que se ponen en juego reputaciones, opiniones, honores, famas y vanidades, sino especialmente como un ámbito en el que, más allá de este nivel representativo, se expresa esa esencia del mundo que rige las acciones de los humanos, la voluntad. En definitiva, la sociedad sería el resultado de la interacción de instintos, pasiones, sentimientos, afecciones y emociones que mueven a los seres humanos. En el trasfondo de esta posición opera la antropología pesimista que tiñe la eudemonología de Schopenhauer.

Así, la sociedad habrá de concebirse como un intento constante de adecuar y compatibilizar todas estas fuerzas irracionales que se encuentran en el fondo de las acciones humanas, pese a su aparente racionalidad, de modo que la represión de esos instintos, esto es, la coacción sobre la voluntad será la constante de toda sociedad: 
tanto que está solo; quien no ama la soledad, no ama tampoco la libertad, puesto que sólo se es libre cuando se está solo: la coacción es la inseparable compañera de la sociedad $^{45}$.

De nuevo, Schopenhauer expone la antinomia entre sociedad y soledad, entendida ésta como autarquía y única posibilidad de libertad. La noción de desarrollo de la propia identidad como autenticidad es crucial en este texto: el ser uno mismo, el desarrollo de la propia personalidad o carácter, sólo es posible en el ámbito de la privacidad. A propósito de esta dialéctica sociedad-soledad, Safranski ha comentado que los Aforismos nos ofrecen un auto-retrato del propio Schopenhauer en su vejez intentando llevar consigo la máxima soledad posible al ámbito social en el que al fin logró irrumpir con fama. Este ideal de autarquía clásica lo encuentra también en Chamfort y La Bruyère, a quienes vincula con el cinismo clásico, proponiendo una especie de filiación de su propio pensamiento:

"Todos nuestros males vienen de no poder estar solos", dice La Bruyère. Tener tanto en sí mismo que no se necesite a la sociedad es ya por esto mismo una gran suerte, porque casi todos nuestros sufrimientos surgen de la sociedad ${ }^{46}$.

En consonancia con esto, es la coacción y represión de la voluntad (como afectividad del individuo) lo que permite la vida social, pues estaría en lucha consigo misma utilizando a los individuos como instrumentos de su absurdo teatro, concepción de la sociedad que lo acercará al modelo de Hobbes, a quien se referirá a este respecto tanto en los Aforismos como en el segundo volumen de El mundo como voluntad y representación.

Ahora bien, no sólo se trata de reivindicar la necesidad de instituciones sociales coercitivas que permitan la vida social, sino también de incidir críticamente en el encubrimiento de esos instintos y pasiones en que se concreta la voluntad metafísica en la vida social. En el segundo volumen de Parerga y Paralipómena, se establece una analogía entre la sociedad y un baile de máscaras, de modo que la voluntad es maquillada y disfrazada mediante un conjunto de trajes y antifaces que representan aquello que es aceptable de acuerdo con la moralidad imperante, cuando en realidad habría unos motivos bien diferentes en el fondo. Esta metáfora del baile de máscaras expresa la dialéctica que opera en el centro del pensamiento de Schopenhauer entre representación y voluntad, al punto que si bien adopta una perspectiva según la cual lo primario es la voluntad y lo secundario la representación, no es menos cierto que son esos disfraces y máscaras que ocultan los intereses de la voluntad los que

\footnotetext{
${ }^{45}$ SCHOPENHAUER, A. P/P, I, p. 416.

${ }^{46}$ SCHOPENHAUER, A. P/P, I, p. 420.
} 
hacen posible una cierta estabilidad social (en la cual, según Schopenhauer, los comerciantes son los más honestos en tanto que no ocultan sus intereses materiales, a diferencia de otros colectivos):

En definitiva nuestro mundo civilizado tan sólo es una gran mascarada. ¡En él se encuentra uno con caballeros, curas, soldados, doctores, abogados, sacerdotes, filósofos y otros tantos más! Pero no son lo que representan: son meras máscaras tras las cuales, por regla general, se esconden especuladores de dinero (moneymakers) [en inglés en el original $]^{47}$.

En este texto tan sólo se hace referencia al interés crematístico, pero en otros se añade la atracción sexual, la vanidad intelectual o el simple orgullo de clase (como el honor caballeresco), pero sobre todo cabe destacar las diferentes máscaras que Schopenhauer enumera: derecho, política, religión, filosofía, filantropía o moralidad serían meras etiquetas que se utilizarían para lograr fines diferentes a los propios que exigirían intrínsecamente estos conceptos como formas ideológicas. La desconfianza hacia estas disciplinas y actitudes se hará patente tanto en su relación con la filosofía de su tiempo como en sus posiciones político-religiosas, que podrían denominarse como conservadoras en algunos aspectos (en política una defensa de la monarquía y de una sociedad jerarquizada, o en religión una apología de sus formas ascéticas y más espiritualistas).

Aquello que se ocultaría tras la máscara no sería más que esa naturaleza humana cruel y despiadada que ya había explicitado en su escrito sobre el fundamento de la moral (E/E, 550), ${ }^{48}$ y que reaparece en este fragmento del capítulo dedicado a la ética en los Parerga:

El ser humano es en el fondo un animal salvaje y terrible. Sólo lo conocemos en el estado de sometimiento y domesticación que se llama civilización: por ello nos horrorizan los estallidos ocasionales de su naturaleza ${ }^{49}$.

La oposición dialéctica entre voluntad y representación se desplaza ahora y se replantea en términos de naturaleza y civilización; la naturaleza humana no sería muy diferente a la de cualquier depredador, quizá tan sólo diferirían en su inteligencia y astucia a la hora de encontrar las formas de manifestar su fuerza. No obstante, si Schopenhauer reconoce que sólo conocemos al ser humano en ese estado de civilización, ¿cómo podemos saber cuál es su naturaleza más allá de esa situación? La extrapolación metafísica que lleva a cabo Schopenhauer consiste en definir la naturaleza humana a partir de esos arrebatos o estallidos en los que la sociabilidad queda en entredicho, convirtiendo en

\footnotetext{
${ }^{47}$ SCHOPENHAUER, A. P/P, II, 8, § 114, p. 191-192.

48 «Para reconocer lo que verdaderamente es el ser humano desde un punto de vista moral hay que leer historias criminales y descripciones de estados de anarquía. Esos millares de individuos que ahí, ante nuestros ojos, se agolpan unos junto a otros en una relación pacífica, cabe verlos como otros tantos tigres y lobos, cuya dentadura está asegurada por un fuerte bozal» (SCHOPENHAUER, A. E/E, 550).

${ }^{49}$ SCHOPENHAUER, A. P/P, II, 8, § 114, p. 192-193.
} 
domesticación y artificio el estado normal de civilización de los humanos y declarando como su naturaleza más propia esos momentos excepcionales en los que se dejan de lado las normas sociales establecidas.

Aunque Schopenhauer no haga explícita su teoría de la sociedad, en cierto modo sigue operando dentro del marco propuesto por las teorías contractualistas clásicas, estableciendo un estado de naturaleza, regido por unos móviles egoístas, y un estado de civilización o social en el que esas fuerzas son sometidas a una serie de instituciones sociales. Sin embargo, en el caso de Schopenhauer esas fuerzas instintivas no son completamente superadas ni transformadas, sino que ellas mismas son el motor oculto de la propia sociedad, de modo que además de ser su condición de posibilidad, son también su principio de evolución y transformación, al modo de la insociable sociabilidad kantiana:

Aquí también se puede hacer la observación de acuerdo con la cual así como, según Kant, la materia sólo existe gracias al antagonismo de la fuerza de expansión y la fuerza de contracción, del mismo modo la sociedad humana sólo existe gracias a la fuerza del odio, o la cólera, y el miedo ${ }^{50}$.

Así pues, los móviles que empujan al estado de sociedad o de civilización no son más que odio, cólera y miedo, lo cual parece indicar la situación caótica de ese estado asocial o de naturaleza que Schopenhauer postula partiendo de esas situaciones de excepción. Ahora bien, no deja de ser paradójico que los instintos o pasiones que empujan a la sociabilidad humana y la posibilitan sean los mismos que puedan disolver una sociedad, pues siguen presentes en ella. La cuestión de fondo, según parece desprenderse de los Aforismos, es que la propia naturaleza humana tiende a la discordia y al caos por su propia constitución, de tal modo que no se trata de dilucidar los factores disgregadores o de corrupción de una sociedad, sino de todo lo contrario, a saber, analizar las condiciones de su estabilidad, en tanto que se presupone la inestabilidad de toda sociedad en la medida en que está compuesta de esos elementos tan volubles y sometidos a tantos afectos y pasiones como los seres humanos.

Si esto es así, una de las problemáticas que suscita el propio planteamiento de Schopenhauer es la de dilucidar cómo se mantiene la cohesión social. ¿Cómo aborda esta cuestión? En este caso el análisis de Schopenhauer se dirige a los mecanismos de cohesión social en principio menos evidentes, pues no atiende al clásico sistema de educación o a la regulación legislativa común, sino que señala un tipo de mecanismos que hacen posible una especie de estado de ánimo colectivo. Según Schopenhauer, en caso de no haber un factor objetivo para lograr esa cohesión, como un peligro colectivo, una esperanza compartida o una información común a todos, se recurre a un factor subjetivo de cohesión.

\footnotetext{
${ }^{50}$ SCHOPENHAUER, A. P/P, II, 8, § 114, p. 195.
} 
Los ejemplos que aduce de este tipo de factor son bien elocuentes: alcohol, té y café; «las botellas son el medio habitual de proporcionar un estado de ánimo común [Stimmung] a la sociedad. Incluso el té y el café sirven a este propósito» ${ }^{51}$.

¿Cómo interpretar esta afirmación? En primera instancia, Schopenhauer aborda el problema de la cohesión social desde una perspectiva crítica refiriéndose a la sociabilidad cotidiana basada en el consumo compartido de ciertos productos y argumentando que lo que permite soportar la presencia de los otros es el efecto de lo consumido, en tanto que sitúa a los individuos en un estado de ánimo común. Pese a todo, aquí se pasa por alto que quizá sea indiferente la sustancia o producto a consumir y que lo importante es el estar con otros, el mero compartir algo. En todo caso, la crítica de Schopenhauer, más allá de dejar de lado esta posibilidad, parece dirigida al objetivo de hacer ver que la afinidad o vínculo colectivo no es alcanzable sino apelando a un estado de ánimo común.

Y esto nos conduce al segundo nivel de la interpretación: los factores objetivos de cohesión citados son noticias, esperanzas, peligros, etc., y si recurrimos al dualismo del planteamiento de Schopenhauer entre voluntad y representación, éstos parece que caerían más bien en el ámbito de la segunda, es decir, estarían referidos más al intelecto que a la voluntad, pues para influir sobre la acción de los individuos media en ellos el nivel representativo y de procesamiento de información (claramente en el caso de la noticia, aunque también en los de la esperanza y el peligro). Sin embargo, en el caso de esos factores subjetivos como el alcohol, el té y el café, parecería que están más vinculados al ámbito de la voluntad, en la medida en que afectan directamente al estado de ánimo de los individuos y los equiparan entre sí creando una especie de estado anímico colectivo. Sólo este tipo de factores serían capaces de superar la naturaleza egoísta de cada individuo y situarlos en una posición de empatía que los cohesione.

No obstante, estos factores subjetivos no son los únicos que cita Schopenhauer, pues también añade el no menos importante mecanismo del recuerdo idealizante:

El recuerdo actúa como la lente convergente en la cámara oscura: lo reúne todo y produce así una imagen mucho más bella que su original. La ventaja de ser vistos así la obtenemos parcialmente con cada ausencia. Porque a pesar de que el recuerdo idealizante necesita un largo tiempo hasta completar su obra, el inicio de la misma empieza al momento. A causa de esto es muy prudente mostrarse a sus conocidos y amigos solo tras significativos periodos de tiempo, cuando en el reencuentro se perciba que el recuerdo ha estado trabajando ${ }^{52}$.

Según esto, el recuerdo es otro mecanismo subjetivo de cohesión social, aunque peculiar en tanto que atañe a individuos particulares como sujetos y objetos del recuerdo, y es para Schopenhauer

\footnotetext{
${ }^{51} \mathrm{P} / \mathrm{P}, \mathrm{I}, 440$.

${ }^{52}$ SCHOPENHAUER, A. P/P, I, p. 440.
} 
un buen motivo para defender la vida retirada de la sociedad. El elemento idealizante del recuerdo opera como un maquillaje que nos permite soportar a los otros y a la vez ser también aceptado entre ellos.

Llegados a este punto, hay que centrarse en la naturaleza de los vínculos sociales como tales. Hasta aquí hemos visto que en los Aforismos habría dos tipos de factores (objetivos y subjetivos), que en cierto modo pueden remitirse al dualismo entre voluntad y representación. A mi juicio, será el propio Schopenhauer quien permita establecer esta vía de interpretación en otros textos, especialmente en el segundo volumen de El mundo, §19, donde explícitamente planteará la existencia de dos tipos de vínculos sociales, lo cual da lugar a dos tipos de comunidad social:

El vínculo, la comunidad y las relaciones entre los humanos se basan, por regla general, en relaciones que se refieren a la voluntad y, en pocas ocasiones en las que conciernen al intelecto: el primer tipo de comunidad se puede llamar material, la otra formal ${ }^{33}$.

La distinción de vínculos referidos a la voluntad y al intelecto genera esta clasificación en comunidades materiales y formales, siendo las primeras denominadas así en tanto que entre los individuos se da una unidad sustancial, esto es, un vínculo afectivo o volitivo, en definitiva, participa la voluntad, mientras que en la comunidad formal el factor de cohesión es la capacidad intelectual, la facultad racional que opera en el ámbito de la individuación. Ejemplos de comunidad material serían, según Schopenhauer, la familia, los círculos de amistades y también las corporaciones profesionales, ámbitos todos en los que se comparte un vínculo sentimental, unos gustos o intereses comunes. En cambio, la comunidad formal sólo se mantiene en tanto que hay unas capacidades intelectuales semejantes entre los individuos y se produce entre ellos un diálogo o intercambio de ideas.

Desde el punto de vista de la metafísica de la voluntad y la ética de la compasión, en el primer tipo de comunidad se da una especie de simpatía moral que Schopenhauer considera como una compasión natural llevada al ámbito social, esto es, en este tipo de comunidad material se pondría de manifiesto una especie de extrapolación de la compasión natural, mientras que en la comunidad formal, basada en el intelecto, el único vínculo sería el intercambio de representaciones y pensamientos, dejando de lado cualquier referencia a la compasión o al sentimiento, lo cual la situaría en un plano secundario respecto a la anterior (téngase en cuenta la síntesis que se daría en la realidad social entre estas dos formas de comunidad, algo que Schopenhauer no parece contemplar, al menos en este texto).

\footnotetext{
${ }^{53}$ SCHOPENHAUER, A. WWV/MVR, II, § 19, p. 268-269, cursivas de Schopenhauer.
} 
No obstante, además de articular estas dos formas de comunidad con el binomio voluntad-representación, ¿se puede interpretar la teoría de la sociedad de Schopenhauer partiendo de la distinción clásica entre naturaleza y sociedad? Como ya se ha señalado, el propio Schopenhauer da pie a ello en la medida en que describe el orden social establecido en su momento histórico como una inversión del orden natural, y por tanto como una corrupción o involución. En cierto modo, está aquí operando el legado rousseauniano en Schopenhauer, filtrado ciertamente por una antropología más cercana a la hobbesiana, lo cual podría parecer una paradoja: el ser humano es un ser agresivo y nefasto, pero el orden social establecido lo corrompe aún más sustituyendo un sistema de relaciones de dominación por otro peor, de tal modo que habría que buscar una ordenación social basada ella misma en algún criterio supuestamente natural. ¿Cuál sería ese criterio?

La argumentación de Schopenhauer tanto aquí como en la dilucidación de la mejor forma de gobierno apunta a la jerarquía intelectual basada en la diversidad de la propia naturaleza. En la naturaleza se darían grandes diferencias entre individuos de una misma especie, pero a la vez habría una organización, jerárquica en muchos casos, que mantendría esas diferencias y posibilitaría una estabilidad social, sometiendo los impulsos y afectos de la voluntad en los individuos de esa comunidad. El referente naturalista de Schopenhauer es clave en su teoría de la sociedad, argumentando algo así como una teoría jerárquica iusnaturalista: el orden natural es positivo y ha de ser imitado en la sociedad, en tanto que se mantiene una jerarquía que hace del reconocimiento de los derechos una contrapartida de la capacidad intelectual de los individuos, esto es, a mayor capacidad intelectual, más derechos, pues sólo mediante este privilegio del intelecto puede mantenerse a raya al elemento volitivo e irracional de la sociedad:

Mientras que la naturaleza ha establecido entre los humanos la más amplia diversidad, tanto en lo moral como en lo intelectual, la sociedad, teniendo a aquélla por nada, los iguala a todos, o más bien pone en su lugar los niveles y diferencias artificiales del estamento [Stand $]$ y el rango ${ }^{54}$.

El propósito de este iusnaturalismo aristocrático-intelectual es acabar con la artificial igualación de derechos establecida en la sociedad, pero este anti-igualitarismo no remite a ninguna instancia tradicional, sino a la diferencia intelectual natural entre los individuos (casi como en el mito platónico de los metales y las almas). Así pues, el intelecto es el criterio para restablecer la jerarquía natural pervertida por la sociedad, más en concreto por la alta sociedad de la burguesía a la que pertenecía el propio Schopenhauer; parece entonces claro que el tono de los Aforismos y en general de todas sus reflexiones socio-políticas tienen un componente biográfico:

\footnotetext{
${ }^{54}$ SCHOPENHAUER, A. P/P, I, 417.
} 
En consecuencia, la sociedad que se llama buena [Gesellschaft, welche man die gute nennt] no sólo tiene la desventaja de que nos ofrece personas que no podemos elogiar ni amar, sino que tampoco nos permite ser según seríamos de acuerdo con nuestra naturaleza ${ }^{55}$.

Luego la incompatibilidad de fondo se produce entre la aristocracia espiritual (reivindicada también en su escrito sobre la filosofía en la universidad) y la "así llamada buena sociedad", frente a la que se reivindica el carácter individual. El aristocratismo de Schopenhauer se evidencia en su distinción de tres tipos de aristocracia: la del nacimiento, la económica y la espiritual, insistiendo en la primacía de la última sobre las dos primeras. Sin embargo, es consciente de que los miembros de esa aristocracia espiritual, especialmente en su juventud, carecen de la sabiduría mundana necesaria para desenvolverse en la sociedad (su propia experiencia en Weimar en casa de su madre podría servir de ejemplo), mientras que esta sabiduría es más propia de aquellos individuos sometidos a los caprichos de la voluntad, y por ello inferiores de acuerdo con el criterio de Schopenhauer. El clasismo intelectualista de Schopenhauer llega incluso al punto de explicar el fracaso de grandes proyectos intelectuales por la intromisión del vulgo en dichos proyectos (P/P, I, 420): así como la ascética consiste en la mortificación de la voluntad mediante el saber místico, en el plano sociológico, la alta sociedad (intelecto) habría de amortiguar la influencia popular (voluntad) para garantizar la libertad y la seguridad del conjunto.

\section{Conclusiones: la teoría de la sociedad como trasfondo de la filosofía política}

Si aquí se ha insistido en utilizar el esquema dualista como clave hermenéutica para exponer las reflexiones sociológicas de Schopenhauer, ha sido con el fin de indicar la conexión de fondo entre Aforismos y el resto de su sistema, lo que permite además avanzar ideas que cobrarán toda su vigencia en la filosofía política de Schopenhauer. En este mismo sentido, y continuando con el elitismo intelectualista expuesto, cabe atender a dos narraciones que utiliza Schopenhauer para exponer la naturaleza de los vínculos reales de toda forma social: la fábula de los puercoespines y el símil de la hoguera. Safranski ${ }^{56}$ ha señalado la importancia de ambas para esta cuestión y su presencia ya en textos muy anteriores a la publicación de los Parerga, en cuyos volúmenes se pueden encontrar las dos. En ambos casos se trata de guardar distancias respecto de los demás, pese a la relativa necesidad de su compañía; llevar la soledad a la sociedad sería el mensaje último de estas dos narraciones:

\footnotetext{
${ }^{55}$ Ibidem.

${ }^{56}$ Safranski, 2001, p. 496-497. 
En este sentido, también se puede comparar la sociedad con un fuego ante el que los prudentes se calientan a una distancia adecuada, pero no lo apresa con la mano como el tonto, quien después de haberse quemado huye al frío de la soledad y se queja de que el fuego quema ${ }^{57}$.

Una sociedad de puerco-espines se apiñaba mucho en un frío día de invierno para protegerse de la congelación con el calor mutuo. Sin embargo, inmediatamente notaron las púas de los otros, lo cual de nuevo alejó a los unos de los otros. Cuando la necesidad de calor los reunió otra vez, se repitió este segundo mal, de modo que tuvieron un tira y afloja entre los dos sufrimientos hasta que hubieron encontrado una distancia ajustada entre sí en la que podían sobrellevar mejor la situación. Así empuja la necesidad de sociedad a los humanos entre sí, surgida del vacío y monotonía del propio interior, pero sus muchos atributos desagradables y fallos insoportables los hacen rechazarse entre sí de nuevo. La distancia media que finalmente encuentran, y gracias a la cual puede existir una comunidad, es la cortesía y las buenas costumbres. [...] Quien, sin embargo, posea mucho calor interior propio, mejor que se aleje de la sociedad para no dar pie a agravios ni a recibirlos ${ }^{58}$.

En primer lugar, cabe destacar que tanto en el símil de la hoguera como en la fábula de los puerco-espines el objetivo de la vida en comunidad es la transmisión y recepción de calor, de un confort y comodidad, lo cual vendría a significar una especie de intercambio afectivo y sentimental mutuo; en definitiva, un vínculo referido a la voluntad más que al nivel de la representación. Este calor afectivo trataría de hacer frente al aburrimiento y vacío interior que vendría a señalar el absurdo de la existencia como tal, de acuerdo con el paradigma general de Schopenhauer. Pero, en ambos casos, la búsqueda de ese apoyo y calentamiento mutuo adolece de un exceso por parte de los imprudentes que se traduce en un escarmiento, un alejamiento y un consiguiente rechazo de la vida social, siendo condenado a la soledad en el sentido negativo de la acepción.

Como consecuencia, Schopenhauer propone la calibración de la distancia adecuada a mantener dentro de la reunión social, esto es, llevar consigo la soledad a la sociedad, como apuntaba Safranski, para evitar ese escarmiento por un exceso de confianza en la vida social. Así pues, se trata de mantener la distancia siempre que uno mismo no sea capaz de proporcionarse a sí mismo ese calor interior que se busca en la sociedad, esto es, si uno no es capaz de lograr el ideal del sabio autárquico de las escuelas eudemonológicas clásicas. Ésta sería la mejor opción, pese a ser la excepción, puesto que para Schopenhauer la sociedad como tal no es sino la potenciación comunitaria de lo peor de la naturaleza humana, resultando que la sociedad humana sería lo peor del mundo: «aunque en este mundo hay muchas cosas malas, lo peor que hay en él sigue siendo la sociedad» ${ }^{59}$; el pesimismo antropológico se traduce así en un rechazo radical de la vida social.

\footnotetext{
${ }^{57}$ SCHOPENHAUER, A. P/P, I, p. 426.

${ }^{58}$ SCHOPENHAUER, A. P/P, II, 31, § 396, p. 560.

${ }^{59} \mathrm{P} / \mathrm{P}, \mathrm{I}, \mathrm{p} .422$.
} 
Si esto es así, la alternativa clásica que hemos utilizado anteriormente entre estado de naturaleza y estado de civilización se revela en el planteamiento de Schopenhauer como una especie de ilusión de alternativas que oculta la mejor solución, la soledad del sabio autárquico. ${ }^{60}$ Incluso la mejor de las sociedades es para Schopenhauer mal negocio frente a la soledad, pues por el mero hecho de ser tal ha tenido que superar y abolir la jerarquía espiritual que la naturaleza habría expresado en la diversidad de los individuos. La propuesta resolutiva de la soledad aristocrática del sabio tendría como corolario socio-político la reivindicación de una jerarquía espiritual, lo que en última instancia se traduce en una forma estatal concreta cuya más urgente función es la de frenar la tendencia de la naturaleza humana a la injusticia, esto es, a la agresión:

¿Qué otra cosa son entonces los Estados, con toda su maquinaria artificial dirigida tanto hacia dentro como hacia fuera y sus medios violentos, sino precauciones para poner límites a la ilimitada injusticia de los humanos? ${ }^{61}$.

Ya para concluir quisiera destacar la concepción liberal del Estado que parece articularse con esta visión de la sociedad. En numerosos textos, Schopenhauer aboga por una concepción minimalista del Estado, es decir, defiende el Estado como institución centrada en garantizar la seguridad y la propiedad de los ciudadanos, una visión alejada del Estado como desarrollo orgánico de una comunidad en la que se subsume la libertad individual (Hegel). Así pues, dentro de la filosofía de Schopenhauer convivirían elementos propios de la tradición liberal (concepción mínima del Estado, derecho de propiedad, etc.) junto con otros más cercanos al pensamiento conservador decimonónico (apología de la monarquía hereditaria, pena de muerte, crítica del comunismo, elitismo, etc.). Para finalizar quisiera destacar el rol determinante que juega la teoría de la sociedad expuesta en los Aforismos en la concepción de la filosofía política de Schopenhauer. Sin embargo, definir con precisión las posiciones centrales de su filosofía política es una tarea que requiere un tratamiento mucho más detallado.

\section{Bibliografía}

La edición de las obras de Schopenhauer utilizadas en este artículo es la siguiente:

\footnotetext{
${ }^{60}$ Würkner ve en esta metáfora de los puercoespines un indicio del liberalismo de Schopenhauer (Würkner, 1989: 96).

${ }^{61}$ SCHOPENHAUER, A. P/P, I, 447.
} 
SchopenHAUER, Arthur. Werke in fünf Bänden. Nach den Ausgaben letzter Hand. Hrsg. von L. Lütkehaus. Zürich: Haffmans Verlag, 1988 (1988-1989). este trabajo:

A continuación, se citan las principales referencias bibliográficas utilizadas en la redacción de

Atwell, John. Schopenhauer on the Character of the World. The Metaphysics of Will. Berkeley: University of California Press, 1995.

Dos SANTOS DuRANTE, Felipe. «Arthur Schopenhauer e a Tradição Jusnaturalista Moderna». In: Revista Voluntas: estudos sobre Schopenhauer. N 1, Vol. 2 (2011): 108-118.

GODART-VAN DER KROON, Annette. «Schopenhauer's Theory of Justice and its Implication to Natural Law». Schopenhauer-Jahrbuch, 84 (2003): 121-146.

GRACIÁN, Baltasar. Oráculo manual y arte de prudencia. Ed. de Emilio Blanco. Madrid: Cátedra, 2007.

HANnAn, Barbara. The Riddle of the World. A Reconsideration of Schopenhauer's Philosophy. Oxford: Oxford University Press, 2009.

Hopf, Michael. «Ansätze zu einer Theorie des 'Minimalstaates' auf der Basis der Rechts- und Staatsvorstellungen Schopenhauers». En SCHIRMACHER, Wolfgang (Hrsg.): Zeit der Ernte. Stuttgart: Frommann-Holzboog, 1982.

HÜBSCHER, Arthur. Denker gegen den Strom. Schopenhauer: Gestern-Heute-Morgen. Bonn: Bouvier, 1982.

INGENKAMP, Heinz-Gerd. «Schopenhauer als Eudaimonologe». IN: Schopenhauer-Jahrbuch, 87 (2006): 77-90.

LÜTKEHAUS, Ludger. Schopenhauer. Metaphysischer Pessimismus und „soziale Frage”. Bonn: Bouvier, 1980.

. «,Ehrensachen meiden”. Schopenhauers Auseinandersetzung mit dem „Princip der Ehre"». In: Schopenhauer-Jahrbuch, 87 (2006): 91-100.

NEYMEYR, Barbara. «Pessimistische Eudemonologie? Zu Schopenhaues Konzeption des Glücks». Schopenhauer-Jahrbuch, 77 (1996): 133-166.

NIETZSCHE, Friedrich. Kritische Studienausgabe. 15 vol. Hrsg. von G. Colli und M. Montinari. Berlin: DTV - Walter de Gruyter, 1999.

ONFRAY, Michel. «Schopenhauer et "la vie heureuse"». Les Radicalités existentielles. Contre-histoire de la philosophie, 6. Paris: Grasset, 2009.

SAFRANSKI, Rüdiger. Schopenhauer und die wilden Jahre der Philosophie. Frankfurt a.M.: Fischer, 2001.

Simmel, Georg. Schopenhauer y Nietzsche. Trad. de Fco. Ayala. Sevilla: Espuela de Plata, 2004. 
SPIERLING, Volker. «Erkenntnis und Ethik», introducción a su edición de A. Schopenhauer, Metaphysik der Sitten. München: Piper, 1985.

1994. . Arthur Schopenhauer. Philosophie als Kunst und Erkenntnis. Zürich: Haffmans,

WoLF, Jean-Claude. «Schopenhauers Liberalismus». Schopenhauer-Jahrbuch, 78 (1997): 63-86.

WÜRKNER, Joachim. «Staatsidee und Schopenhauer-Welt». Archiv für Rechts- und Sozialphilosophie, 75 (1989): 82-103.

ZIMMER, Robert. «Philosophie der Lebenskunst aus dem Geist der Moralistik. Zu Schopenhauers Aphorismen zur Lebensweisheit». Schopenhauer-Jahrbuch, 90 (2009): 45-64.

. Arthur Schopenhauer. Ein philosophischer Weltbürger. München: DTV, 2010.

Recebido: 01/11/12

Received: 11/01/12

Aprovado: 21/12/12

Approved: 12/21/12 